\title{
How I was almost aborted: reflections on a prenatal brush with death
}

\author{
Jonathan M Berkowitz Philadelphia, USA
}

\begin{abstract}
Author's abstract
After recently meeting with his biological parents, the author-a 29-year-old-married male-learned he had been an hour away from being aborted, being 'saved' only by extraordinary circumstances. In the paper the author reflects upon previous strong pro-choice beliefs and reasserts his commitment to a pro-choice philosophy, integrating his new personal experience. The paper pays particular attention to the biological mother's experience and how her fresh insights have reinforced the author's views on abortion.
\end{abstract}

In 1987 I published an essay in the Research fournal of Philosophy and Social Sciences (1) defending a woman's right to abortion. In this paper I challenged in a detached rational manner two questions often posed by anti-abortionists: 'What if Einstein's or Mozart's parents decided to abort them?' and 'How would you feel if you were aborted?' Shortly after writing this article, I acquired intimate knowledge of an individual who came within an hour of being aborted and now, as an adult, is eager to tell how this experience affected his views on abortion. I love and care deeply for this person who is, as far as I'm concerned, more important than any scientist or musician. As you have probably guessed by now I am this person and while I can't speak for Wolfgang Amadeus Mozart or Albert Einstein I can certainly speak for myself.

My unusual story began five years ago when I developed chronic asthma which left me steroiddependent. My parents had the good judgement to inform me at an early age of my adoption and I accepted this knowledge as a natural part of myself. So casual was my attitude I devoted little thought as to who my biological parents were. Suddenly, I was painfully aware that I did not have the benefit of knowing my true medical history and wondered if my recent malady might have a genetic basis. Given these considerations I decided to locate my biological parents in the Spring of 1989 with the intention of obtaining complete medical histories. Two months later the adoption agency discovered the whereabouts of my

\section{Key words}

Abortion; adoption; biological father; biological mother; natural parents. natural parents both of whom lived within five miles of where I was raised. With this knowledge I could no longer contain my curiousity and promptly requested separate meetings with my biological parents. I was fortunate to meet them during the Summer of 1989 and while the meetings did not shed any light upon the cause of my asthma the experience was well worth the effort. Not only did I obtain valuable medical information but I also gained, on my biological father's side, an extended family of two half-sisters and one half-brother all of whom I see on a regular basis. Unfortunately, the same cannot be said of my biological mother who, still plagued with guilt, desires as little contact with me as possible. Though there are many intriguing details concerning my past, undoubtedly the most fascinating was the discovery of how close I came to being aborted and the way this knowledge has influenced my previously strong 'prochoice' beliefs concerning abortion.

I was born in 1961, a time when pregnancy out of wedlock was a tremendous taboo and source of great embarrassment. Consequently my biological mother suffered intense family pressure, to which she eventually yielded, to have her illegitimate fetus aborted. On the appointed morning my biological mother was ready and patiently waiting for her father who had, during the previous evening, demanded and obtained the money for the abortion from my biological father. Fortunately for me, my biological mother's father was a habitual gambler who had promptly lost the money on a bet that very same evening. Thus, for the time being, the abortion was off. However, the incident broke my biological mother's resolve to have an abortion and after much argument she was whisked off to a home for unwed mothers where I was born and given up for adoption.

As my biological mother related the debate surrounding my fate an existential nightmare immediately flashed into my mind. Like something out of the 'Twilight Zone' I suddenly feared she would inform me, 'but dearie, you were aborted', and I would realise my entire existence had been nothing more than an abortion-induced fetal hallucination. This surrealistic vision was quickly replaced by genuine horror as I grasped how close beside me death once stood. My life had hung between the emotions of a 
young, scared pregnant girl and the whims of her parents. I felt like a man who had just beaten a death sentence. Such an experience certainly has the potential to force a person not only to re-evaluate his life but also to be thankful for the life he has. For me, the old adage - 'you don't know what you have till you [almost] lose it' - proved to be particularly poignant. Nonetheless, despite my contemplation of the prospect of my own non-existence and after extensive reflection, I harbour absolutely no doubts concerning a woman's right to have an abortion.

During our meeting I learned that my biological mother had wavered considerably between giving birth to me and having me aborted. Even on the morning she was to undergo the abortion she was still uncertain as to what her true feelings were but was resigned to allow her parents to take control of the situation. It was not until several weeks after her entry into the home for unwed mothers that she began to resent the pregnancy and unequivocally to desire an abortion. Happily for me, this time, a willing doctor was not available. The forced pregnancy however left significant and lasting emotional scars on my biological mother. Throughout the conversation I had with her, I beheld her revulsion at being the unwilling bearer of a fetus. Without remorse my biological mother told me she 'resented the fact that [she] was forced to carry a child [she] did not want', a child that 'invaded [her] body'. Twenty-nineyears would seem to be sufficient time for most psychological wounds to heal; yet the emotions she laid bare were fresh and burned in her eyes. I could plainly see in her the stigma and shame she had buried for so long and could not exorcise. The sad truth is that my biological mother has never recovered from her out-of-wedlock pregnancy.

Admittedly she did not receive the best guidance and is indeed herself, along with my biological father, largely responsible for much of what happened in 1961. Yes, both she and my biological father should have been more careful in the first place. Yes, her indecision added to her problem. Yes, knowing her father was a gambler and could not be trusted with money, she should have taken more control of the situation. It is very easy to say what should have happened - the way she should have acted. Yet the truth is that she was a confused and terrified seventeenyear-old girl who was overwhelmed by her own desperate circumstances. It is true that in their youth both my biological parents were irresponsible and a serious mistake was made as a result of their irresponsibility. Nonetheless, my biological mother should never have gone through what she did go through these past twenty-nine years. To be honest, at the present time my biological mother does not have much of a life. At the age of forty-six she still lives at home with her mother and is grossly under-employed. Though I am certain much else has figured in my biological mother's 'life equation' I can't help but wonder how different things might have been for her had abortions been legal in 1961 .

It is not only because of the mother's well-being that I support a woman's right to abortion; more importantly, I support it for the children's sake. I can't predict what my life would have been like if I had been raised by my biological mother, suffice it to say I have little confidence in her parenting ability. I was fortunate to be adopted and raised in a decent home. I can't complain - so far I've made an excellent life for myself: I am happily married and with any luck I'll be a father in the next year. Professionally speaking, in addition to an increasingly successful career as a writer I am a first-year medical student at Thomas Jefferson Medical College in Philadelphia. Life has been very good to me. However, after living several years in New York City and now in Philadelphia I have seen thousands of unwanted boys and girls, many of whom probably never had a chance of being adopted and who are destined to live in homes filled with hate and suffering. Every day teenage girls, themselves only two years removed from 'Sesame Street' lunch-boxes, flood our hospitals, giving birth to sons and daughters who will all too often never know their fathers. Of course not all children born out of wedlock are automatically guaranteed a horrible life, just as all children born in wedlock are not guaranteed a happy life. Regardless of the exceptions, we are all too familiar with the plight of unwanted children. For me, the bottom line is that I could easily have been one of those unfortunate children. I could have been the ball and chain around my young mother's ankle. I am the exception to the rule - I was adopted and am now a happy and productive member of society. Yet, despite how much I savour life, I still don't believe that the existence of one Jonathan Berkowitz is worth the social and economic costs of the innumerable unknowns who are oftentimes discarded as unceremoniously as yesterday's newspaper.

Fonathan Mark Berkowitz is a writer and medical student at Thomas fefferson Medical College.

\section{Reference}

(1) Berkowitz J M. What right to life? Research journal of philosophy and social sciences 1987; 2: 71-81. 